\title{
Addressing corruption in climate change water adaptation
}

\author{
Maria Jacobson $\cdot$ Håkan Tropp
}

Published online: 22 May 2010

(C) Springer Science+Business Media B.V. 2010

\section{Introduction}

With nearly 1.2 billion people in the world not having guaranteed access to water and more than 2.6 billion without adequate sanitation, governments around the world are facing a global water crisis with devastating consequences for development and poverty reduction. What is less known is that the crisis of water is a crisis of governance, with corruption as one root cause. To achieve the United Nations Millennium Development Goals (MDGs) for water and sanitation alone, corruption is believed to inflate the overall costs by more than US $\$ 48$ billion (Transparency International and Water Integrity Network 2008).

With the onset of climate change and a businessas-usual approach, the world's water crisis is bound to deepen as water is the primary medium through which climate change will have an impact on people's livelihood, ecosystems and economies. In Africa alone by 2020, 75-250 million people are expected to be exposed to increased water stress due to climate change (World Water Development Report

M. Jacobson · H. Tropp ( $\bowtie)$

Stockholm International Water Institute, SIWI,

Drottninggatan 33, 11151 Stockholm, Sweden

e-mail: hakan.tropp@siwi.org

URL: www.watergovernance.org; www.siwi.org

M. Jacobson

e-mail: maria.jacobson@siwi.org
2009). Climate changes are likely to be rapid and events of flooding and droughts are expected to become more intense and frequent in many parts of the world. Such changes would result in increasing risk and vulnerability to not only environmental sustainability but also economic growth and poverty reduction. For example, the Maldives, facing dire consequences of sea-level rise, are already considering buying land on the South Asia mainland as a coping mechanism to the risks of sea water destroying fresh water sources and eventually flooding great parts of the Islands.

In addition to the rising demands for water due to climate change, overuse and pollution, poor governance (including corruption), population and economic growth and with that changing consumer preferences all contribute to the widening gap between available water and water demands. Water scarcity leads to economic losses, increased competition, social tension, conflict and more.

Responses to climate change include both mitigation and adaptation measures. As part of the global response to climate change, considerable investments are expected through different institutions and governance processes which all pose potential corruption risks. For mitigation measures, potential corruption risks entail lax control from regulatory pollution control authorities, loopholes in international financing mechanisms such as the Reducing Emissions from Deforestation and Forest Degradation (REDD) and the Clean Development Mechanism (CDM), 
carbon trading, green branding etc. This article however, focuses on the corruption aspects related to climate change adaptation measures in water.

\section{Adaptation: a water sector response}

Water management has always been about coping with climate variability and thus changing conditions of water resources availability. For example, any farmer has to cope with intra-and inter-seasonal water resources availability fluctuations. Managing risks and uncertainties and applying adaptive measures have thus been a recurring theme for good water management practices.

In many parts of the world the threatening climate change introduces dramatic increases of risk and uncertainty. The anticipated magnitude of climate and hydrological change is at unprecedented levels and in some cases it threatens to extinct whole societies, particular in tropical zones, where sea-level raise and increased floods and droughts will make dramatic ecological, economic and social impacts. While many so called developed countries-such as the Netherlands and England - can afford to invest heavily in infrastructures and practices to minimize risks associated with sea-level rise, most developing countries already have huge difficulties to generate sufficient funds to for example provide universal primary education and health care, basic water supply and sanitation services and water resources management.

Climate change impacts will hit countries in different ways and therefore adaptation measures need to be different. For example, as mentioned above, the President of the Maldives recently announced that government will establish a trust fund to buy land abroad, possibly in India or Sri Lanka, due to the threat of rising sea levels (BBC News, 10 November 2008). The funds will be generated through the country's tourism revenue. The government perceives this as an insurance policy for the worst possible scenario of the country being immersed by the sea. However, in other cases impacts will be less dramatic and also entail positive economic opportunities. So, possible adaptive measures are found along a continuum of very extreme impacts to situations of very little impacts. So far, debates on adaptive measures have failed to clarify such different options for countries and above all to make the link between different climate induced impacts and required adaptive measures in relation to available financial resources. In working with adaptive measures past climate and hydrological data will be obsolete, but yet scenario-based water resource planning is in its infancy and there are few models containing high resolution data of how future water supply and demand will play out within a particular country.

The international community such as through the Convention on Climate Change has called for a need to apply climate change adaptation measures, but in many cases this will be hard to apply on the ground due to governance and economic realities of poor developing countries and a lack of understanding of what is prioritized and needed within those countries. For example, climate change impacts will be different between countries but also within countries and developing countries may see other priorities than donors of how to cope with climate change impacts. This article will not be able to develop models of adaptive measures but it is clear that:

1) No blueprints will apply and countries will have to develop their own intrinsic adaptive models and investment strategies;

2) Depending on the economy of a country it has to consider the range of different low to high cost and small- to large-scale technical and infrastructure solutions;

3) Any country would have to consider how to apply a good mix of water supply and water demand measures;

4) Improved governance, including anti-corruption measures, is critical for policy implementation and for optimizing investments as well as for reducing investment risk to rise both public and private investments;

5) Ecological protection can many times be an effective adaptive measure and;

6) The evidence of what adaptive measures that are most cost effective is yet rudimentary. One sound strategy to follow is the "no-regrets policy", that is, to invest in measures that also will have more immediate benefits. The "no-regrets" means that countries should continue, and also try to increase, investments to improve water resources management, incentives towards less or more water intense crops, the implementation of zonal 
planning and protection of certain ecological zones, continued investments in both physical and social infrastructures, such as water storage, basic education, health-care and other basic services etc. However, still there is little evidence of the development impacts of various options within a "no-regrets" approach.

A recent report from the private sector suggests that to bridge the world's water resources gap between water supply and demand by 2030 requires massive investment. If only supply measures are considered it will require annual investments of US\$200 billion, but if a more balanced supply and demand approach is used it will require investments around US\$50-60 billion per year (The 2030 Water Resources Group 2009). A worrying sign is that most governments tend to think that "big problems" must be resolved by "large-scale" and often high cost measures. For example, most decision-makers around the world still seem to be ignorant that ecological protection can be a useful adaptive measure, such as maintaining wetlands for flood protection.

As described above going for large-scale is only but one option that most developing countries would not be able to afford for the foreseeable future, at the same time, as we shall see below, such large-scale solution preferences can open up for major corruption risks.

\section{Vulnerability of water sector to corruption}

The water sector is particularly vulnerable to corruption. First of all, although management of water includes many political, environmental and social dimensions, including corruption, it is still largely approached as an engineering challenge. This has consequences in relation to corruption since the technical complexity required to design and construct water infrastructure projects leaves little room for non-technical actors to monitor contract implementation or to assess whether decisions are made on a sound and cost effective basis. Apart from the technical complexity, the water sector is also complex in the sense that it involves a multitude of actors. This leaves water governance dispersed across political boundaries and different agencies which makes effective regulation and oversight difficult and opens up for many loopholes to exploit. Another reason is that the water sector is highly capital intensive compared to many other areas because of the many large and complex infra-structure investments. This makes procurement and contract implementation easy to manipulate. Further, most of the major growth markets for private sector participation in water and sanitation are in countries with high risks of corruption, posing particular challenges for both domestic and foreign investors to act with integrity.

As a sector that delivers a basic public service necessary for human life and dignity, the first to suffer from corruption in water are often the one with the weakest voice, the poor and marginalized who have limited ability to demand accountability. Moreover, environmental interests many times lack a strong voice to influence water resources allocation and use decisions. Finally and directly linked with climate change-but compounded by population growth, changing dietary habits and economic development-water is becoming increasingly scarce. The less water available, the higher corruption risks emerge in control over the water supply (Transparency International and Water Integrity Network 2008).

\section{What is the link between climate change adaptation and corruption?}

\subsection{Climate fund}

One of the few outcomes of the COP15 Summit was to set up a new fund aimed at helping poor countries adapt to and mitigate the effects of climate change, the so called Copenhagen Green Climate Fund. So far, developed countries have committed USD 30 billion for short-term adaptation and mitigation measures for poorer countries, and have committed to raise a further $\$ 100$ billion by 2020 to the fund (United Nations News Service 19 December 2009).

It is still unclear how this multi-billion dollar fund will be managed and there are different opinions over who should be tasked to oversee it. Whereas the US and the EU want to see the fund managed either by existing international institutions such as the World Bank or by bilateral institutions, the developing 
countries want a new body to control the fund, which would be under direct control of the Conference of Parties, i.e. the 192 countries that have signed the United Nations Convention on Climate Change (UNFCCC). While the developed countries argue that using existing mechanisms would ensure more accountability to their respective tax payers, the developing countries want more direct access to the funds and to avoid delays associated with existing institutions. Many developing countries also want few restrictions on how the money should be used since they view it as a compensation for the damages related to climate changes caused by the developed world. Using the 'guilt card' of the "North" having caused climate change can also lead to consequences of less rigour in how funds are being used.

Irrespective of what the funding mechanism will look like, it is clear that a large chunk of the money will be channelled to countries with weak governance structures and low absorptive capacity i.e. having difficulties to use all the funds allocated to certain projects within a stipulated time-frame. This in combination with an anticipated rapid disbursement poses great risks to corruption, which is rampant in many of the target countries. When setting up the modalities for the fund it is therefore crucial to invest in governance mechanisms and to allow enough time to ensure that proper checks and balances and transparent procedures are in place in order to make maximum use of the funds.

During recent years international development cooperation has moved towards budget support and so called sector wide approach (SWAp). This means that the main bulk of donor funding for a particular sector supports a single sector policy and expenditure programme, under leadership by recipient governments and using their procedures to disburse and account for all funds. In practice this has meant that it is now more difficult for donors to follow-up and monitor their own particular funding. While, this has had positive impacts on stronger programme ownership by recipient countries, it has also created new accountability challenges between many donor and recipient governments as well as between donor governments and their tax-payers. Many governments are in the processes of strengthening their internal systems of checks and balances but it is clear that this type of funding has implied new corruption risks.

\section{Preference for infra-structure investments requires proactive anti-corruption measures}

Climate change adaptation currently receives relatively little funding-only little more than $5 \%$ of the total funds available for mitigation initiatives (Global Humanitarian Forum 2009). Despite that, there seems to be a preference for costly infrastructure projects to adapt to climate change, instead of low cost solutions that often are the most effective ones. Many of these low cost solutions deal with governance. Examples of such governance interventions are improved land tenure and zoning restrictions that can protect both ecological sensitive areas and the most vulnerable and marginalised communities from having the safest and most productive land grabbed by powerful elites.

The preference among development practitioners for expensive adaptation options could have many reasons. Donors are often under pressure to disburse money rapidly and have little capacity and desire to micro-manage many small projects, especially where they increasingly are going for budget support and so called SWAp. Another reason could be the need to show tangible project outputs 'on the ground' or simply lack of knowledge of the low cost options available.

Regardless of the reason, given the emphasis on investing in expensive infrastructure, development practitioners need to be aware of and take action against the corruption risks associated with infrastructure projects such as loopholes in the procurement procedures, the effects of non-transparent privatisation processes and more. If not, well intended projects may in fact cause more harm than good by serving the interests of a narrow elite at the expense of the environment and poor communities in marginal areas who are most vulnerable to climate change.

This is not to argue against the need for investing in infrastructure as a way of adapting to changing climates. In many countries such measures are much needed, but importantly it has to be done with necessary environmental, social and corruption safeguards.

\section{Water scarcity drivers}

It should not be forgotten that there are many other drivers to the growing water challenges than 
climate change. These include demographic change, economic growth, change of consumer preferences, such as consuming more water intense products, and bad planning and governance. There is also a tendency by many decision-makers to use climate change as an excuse when bad planning, management and corruption are causing problems. For example wetlands are increasingly exploited for housing and other urban activities. Such areas will be regularly flooded. A particular case in point is the example of the Mau forest in Kenya (UNEP 2005). The deforestation of Mau is causing an environmental disaster, resulting in a reduction in groundwater, wiping out farms and drying up rivers and lakes. The Mau system of forests is the biggest of Kenya's five water sources. It is the source of 12 rivers, which sustain five lakes. Already, the rivers and lakes are drying up. Out of convenience some politicians used to blame the ecological destruction on climate change, but land title deeds were handed out as a vehicle for political patronage. Huge land areas were allocated to political elites and their supporters. Ultimately, the Mau forests have come under huge ecological pressure due to clearing of forests for farming land. The ecological crisis of Mau is due to a combination of bad governance and politics, increasing pressure on land and water resources, population growth as well as effects of drier climate. The current government is now planning forced evictions but this also entails political dimensions of tribalism as well legal aspects of title deeds. While certain persons have acted in good faith when deeds were received, others obtained deeds through corruption and political patronage. Many of those being evicted are poor peasants with little alternate options to earn an income. Ultimately, the consequences of political patronage and bad governance, worsened by climate change and population growth etc., will strike hard on ecological systems, economic activities and poverty reduction efforts.

\section{How can climate change induced corruption be tackled?}

Corruption and other forms of bad governance mean that it will be more costly and take longer time to adapt to climate change. In practice this can mean irreversible ecological impacts and that development and poverty reduction will be slower or in some cases even prevented. Reducing corruption will have positive impacts on climate change adaptation and development itself! But how can we get there?

It can be tackled! And change has to come both from the top and bottom. But yet corruption is a very politically sensitive issue in many countries. There is currently a growing movement to improve water integrity and accountability. An increasing number of governments are applying measures to improve good governance principles, such as increased transparency and multi-stakeholder participation in decision-making and internal checks and balances. At global and national levels, accountability and integrity multi-stakeholder networks are being established, such as the Water Integrity Network, WIN (see www.waterintegritynetwork. net). Private sector is increasingly applying anticorruption measures. Many of the required tools and methodologies to improve accountability are already developed and are waiting to be applied on larger scales. But the application of specific tools and methodologies must go hand in hand with unrelenting commitment from political, business and civil society leaders.

It takes two to tango! The role of donors and governments at the receiving end demands mutual accountability. International development partners have a responsibility to ensure that their funds are channelled through accountable institutions and that donors themselves are not turning a blind eye or are part of dubious practices. This requires effective monitoring focusing on results and local solutions. Ultimately, much of the funds will be handled by the private sector in applying adaptation measures. Private sector cannot ignore this issue and they too have to become more accountable and increasingly apply measures to reduce corruption.

Without the proper incentives and effective monitoring, corruption will significantly undermine climate change adaptation and mitigation initiatives, thus thwarting the Millennium Development Goals and sustainable development agendas-the fundamental goals of the climate and related environmental agreements. 


\section{References}

Global Humanitarian Forum (2009) Adapting to climate impacts. Report from focus session on financing urgent adaptation, global humanitarian forum 2009: human impact of climate change, 23-24 June 2009, Geneva, Switzerland. http://www.ghf-ge.org/Portals/0/pdfs/Financing_urgent_ adaptation.pdf [Accessed May 2010]

BBC News, 10 November 2008, Plan for New Maldives Homeland. http://news.bbc.co.uk/go/pr/fr/-/2/hi/south_asia/ 7719501.stm [Accessed May 2010]

The 2030 Water Resources Group (2009). Charting our water future: economic frameworks to inform decision-making
Transparency International and Water Integrity Network (2008) Global corruption report: corruption in the water sector. University Press, Cambridge

United Nations Environment Programme, UNEP (2005) Maasai Mau forest status report 2005. Nairobi, Kenya

United Nations News Service, 19 December 2009, Climate change deal marks an 'essential beginning,' Ban says. www. un.org/apps/news/story.asp?NewsID=33305 [Accessed May 2010]

World Water Development Report (2009) Water in a changing world. Earthscan, UNESCO Publishing, London 